\title{
EFFECT OF ANISE SEEDS (PIMPINELLA ANISUM L) AND ACTIVE DRY YEAST (SACCHAROMYCES CEREVISIAE) SUPPLEMENTS AS FEED ADDITIVES ON THE PRODUCTIVE PERFORMANCE OF LACTATING EGYPTIAN BUFFALOES
}

\author{
M.T. Sallam ${ }^{1}$; M.A. El-Barody ${ }^{1}$; M. Abd-Allah ${ }^{2 *}$ and M.H. Tawfik ${ }^{2}$ \\ ${ }^{1}$ Department of Animal Production, Faculty of Agric. Minia Univ, Minia, Egypt. \\ ${ }^{2}$ Department of Animal Production, Faculty of Agric.Al-Azhar Univ, Assiut Branch, Assiut, Egypt. \\ *Corresponding author. Muhtaram Abd-Allah Mohammed. \\ Mobile (+20)01006957157 E-mail: mohtaram_a_m_e@yahoo.com, $\underline{\text { muhtaram@azhar.edu.eg }}$
}

(Received 9/9/2018, accepted 21 /10/2018)

\section{SUMMARY}

\begin{abstract}
$\mathrm{T}$
This study was conducted to evaluate the effect of supplementing rations with Anise seeds (AS) and Active dry Yeast (Y) in Egyptian buffaloes on milk yield, milk composition and some blood parameters. Twelve multiparous pregnant buffaloes in third and fourth lactation, weighing in average $465 \pm 2.5 \mathrm{~kg}$ and at 6 weeks before parturition were divided randomly into four equal groups. Control group $\left(\mathrm{T}_{1}\right)$ fed concentrate feed mixture, Egyptian clover and wheat straw without supplements (basal diet). The $2^{\text {nd }}$ group $\left(\mathrm{T}_{2}\right)$ was given the basal diet plus 50 gram headlday of Anise seeds. The $3^{\text {rd }}$ group $\left(\mathrm{T}_{3}\right)$ was given the basal diet plus 20 gramlheadlday of active dry yeast (Saccharomyces Cerevisiae). The $4^{\text {th }}$ group $\left(\mathrm{T}_{4}\right)$ was given the basal diet plus 10 gram of active dry yeast and $25 \mathrm{~g}$ of Anise seeds thead \day. Buffaloes were fed individually and the experimental period started form 6 weeks before calving and extended for 15 weeks after calving periods. The results indicated that the dry matter intake (DMI) was significantly $(\mathrm{P}<0.05)$ increased in $\mathrm{T}_{2}$ and $\mathrm{T}_{4}$ than control treatments. Also, Anise seeds and Yeast supplements significantly $(\mathrm{P}<0.05$ or $\mathrm{P}<0.01)$ increased nutrient digestibility (DM, OM, CP, EE). Total milk yield, daily milk yield and fat, lactose, total solid percentage significantly $(\mathrm{P}<0.05$ or $\mathrm{P}<0.01)$ increased in treated buffaloes. Also, calculated efficiency of milklDMI was improved $(\mathrm{P}<0.05)$ in treated buffaloes. However, values of blood plasma for total cholesterol and triglyceride concentrations significantly $(\mathrm{P}<0.01)$ decreased in treated buffaloes compared to control treatment. The addition of Anise seeds and Yeast increased $(\mathrm{P}<0.05)$ the levels of blood plasma $\mathrm{T}_{3}, \mathrm{~T}_{4}$ hormones in lactating buffaloes.
\end{abstract}

Keywords: Anise seeds, dry yeast, Egyptian buffaloes, milk yield, triglyceride.

\section{INTRODUCTION}

Egypt has approximately 3.8 million heads of buffaloes and their milk contributes to $60 \%$ of the total milk production in Egypt (Ministry of Agriculture, Dokki, Egypt, 2003). Buffalo's milk preferred by the Egyptian consumers for its high percent of fat and good tastes. It is whiter in color than local cow's milk. Therefore, buffalo's milk gets almost double the price of cow's milk in the local market (Abdel-Aziz, 2005). Generally; there is an increasing demand for buffalo's milk in Egypt. Many attempts have been made to improve milk production, increase growth rate and profits of buffaloes. Feed additives are important material that can improve feed efficiency, milk yield and composition of lactating buffaloes (Khattab et al., 2010). Dietary supplements of live yeast culture had been reported by El-Ashryet al., (2001) and Abd El-Hakeem, (2011) to improve feed utilization, milk production and composition in buffaloes. Also, El-Garhy and Mustafa (2007) reported that Anise seeds (Pimpinella Anisum L) might be useful as a milk stimulant for lactating animals. Sallam et al., (2012) reported that Anise seeds diet supplementation could be used as natural growth promoters in ewe diets to improve milk yield, milk composition. Generally, feed additives supplementies in the diet led positive (increase) or negative (decrease) or unchanged effect on the concentrations of blood (Abo El-nor et al, 2007, Khattab et al, 2011) on lactating buffaloes. The objective of this study was to evaluate the effect of Anise seeds (Pimpinella Anisum L) and Active dry Yeast 
(Saccharomyces Cerevisiae) supplements as feed additives on lactating buffalo's performance, feed efficiency, milk yield, milk composition, and some blood parameters.

\section{MATERIALS AND METHODS}

This study was carried out at the experimental farm station belonging to the Animal production Department, Faculty of Agriculture, Al-Azhar University, Assuit Branch, during the period from 2014 to 2016 years.

\section{Experimental animals and feeding system.}

Twelve pregnant buffaloes in the third and fourth lactation, weighing in average $465 \pm 2.5 \mathrm{~kg}$ and at 6 weeks before parturition were divided randomly into four equal groups. Control group $\left(\mathrm{T}_{1}\right)$ fed concentrate feed mixture, Egyptian clover and Wheat Straw without supplements (basal diet). The $2^{\text {nd }}$ group $\left(\mathrm{T}_{2}\right)$ was given the basal diet plus 50 g\headlday of Anise seeds. The $3^{\text {rd }}$ group $\left(\mathrm{T}_{3}\right)$ was given the basal diet plus 20 glheadlday of Active dry Yeast (Saccharomyces Cerevisiae). The $4^{\text {th }}$ group was given the basal diet plus $10 \mathrm{~g}$ of Active dry Yeast $+25 \mathrm{~g}$ of Anise seedsheadlday. Buffaloes were fed individually and the offered daily feeds were assessed to cover the maintenance and production requirements for each animal according to Shehata (1971). Buffaloes were fed individually and the experimental period started from 6 weeks before calving and extended for 15 weeks after calving period. Rations were offered twice daily at 7.00 a.m and 3.00 p.m. Fresh water and mineral salts were continuously available during the trial period. Daily amounts of feed consumed and the residuals were weight and recorded. The chemical compositions of ingredients are shown in Table (1).

Table (1). Chemical composition of concentrate feed mixture (CFM), Egyptian clover (EC) and wheat straw (WS), anise seeds (AS), active dry yeast (Y), percentage of dry matter.

\begin{tabular}{lccccc}
\hline \multirow{2}{*}{ Item } & \multicolumn{3}{c}{ Diet ingredient } \\
\cline { 2 - 6 } & CFM & Egyptian clover & Wheat straw & Anise Seed & Yeast \\
\hline Dry matter (DM) \% & 89 & 17.19 & 90.63 & 90.24 & 92.23 \\
Organic matter (OM )\% & 88.5 & 87.29 & 88.2 & 89.47 & 94.77 \\
Crude protein (CP) \% & 14.32 & 13.49 & 3.00 & 17.47 & 33.67 \\
Crude fiber(CF) \% & 15.1 & 23.37 & 39.33 & 19.2 & 6.24 \\
Either extract (EE )\% & 4.22 & 1.68 & 1.73 & 26.35 & 10.42 \\
Nitrogen free extract (NFE) \% & 54.86 & 48.75 & 44.14 & 26.45 & 44.44 \\
Ash \% & 11.5 & 12.71 & 11.8 & 10.53 & 5.23 \\
\hline \hline
\end{tabular}

\section{Chemical analysis:}

Fecal samples were collected at the last week of the experimental period twice daily at 7.00 a.m and 4.00 p.m directly from the rectum of each buffalo then it was stored at $-5^{\circ} \mathrm{C}$ until analysis. Sub samples of fecal and experimental ration were dried at $105^{\circ} \mathrm{C}$ in a forced air oven for 3 hours or till reached a constant weight to determine dry matter $(\mathrm{DM})$, while other subsamples were dried on $60^{\circ} \mathrm{C}$ in a forced air oven till constant weight for feed and fecal nutrients determination. Proximate chemical analysis was applied according to A.O.A.C (1995). Organic matter (OM) and Nitrogen free extract (NFE) were calculated. Digestibility coefficients of DM, OM, CP, CF, EE and NFE, were determined using acid insoluble ash (AIA \%) as natural marked according to Van keulen and Young (1977). The nutritive values as total digestible nutrients (TDN) and digestible crude protein (DCP) of the experimental rations were calculated. 


\section{Blood plasma constituents.}

Heparinized blood samples were collected from the jugular vein from each of the experimental buffaloes at the last week of feeding trial. Blood samples were centrifuged at 4000 r.p.m for 20 minutes for separation of plasma that were stored at $-20^{\circ} \mathrm{C}$ till analysis. Part of blood plasma samples was used to measure, by spectrophotometer, the concentration of total cholesterol according to Ellefson and Caraway (1976), triglycerides according to Stein (1987). The second part of blood plasma samples was used to determine the concentration of triiodothyronine $\left(\mathrm{T}_{3}\right)$ (Chopra et al, 1971), thyroxine $\left(\mathrm{T}_{4}\right)$ (Irvine and Standeven 1968) and prolactin according to (Dowininget al., 1995) using radioimmunoassay technique.

\section{Milk yield and Composition:}

Buffaloes were hand milked twice daily at 6.00 a.m and 4.00 p.m during the period from the fifth days of calving till the end of the $15^{\text {th }}$ week thereafter and milk yields were recorded individually at each milking. Milk samples were collected from experimental animals every two weeks. The samples were kept under freezing at $-20^{\circ} \mathrm{C}$ until the chemical analysis. All samples were mixed for each animal in one sample for analysis. Milk sample were analyzed for fat, total solids, total protein and ash (Ling, 1963), solids not fat (SNF) was calculated by difference. Lactose percentage was calculated as following: Lactose $\%=100-$ (total protein $\%+$ fat $\%+$ ash $\%+$ moisture \%), according to Economides (1986).

\section{Statistical Analysis:}

The statistical analysis system (SAS, 2008) was used for least square of variance for separated measures of milk yield, milk composition, feed efficiency parameter and data of blood plasma analysis. The following model was applied: $Y_{i j}=\mu+A_{i}+E_{i j}$. Where: $Y_{i j}=$ the studied trait, $\mu=$ the overall mean. $A_{i}=$ the effect of treatments $(i=1,2,3,4)$. $E_{i j}=$ the experimental error. $\left(0, \sigma^{2}\right)$. Significant differences among means for each trait were detected using (Duncan's multiple range tests, 1955).

\section{RESULTS AND DISCUSSION}

\section{Feed intake and nutrients digestibility:}

Dry matter intake (DMI) for buffaloes fed $\mathrm{T}_{4}$ ration was significantly $(\mathrm{P}<0.05)$ higher than those recorded for $\mathrm{T}_{1}, \mathrm{~T}_{2}$ and $\mathrm{T}_{3}$ ration as shown in Table (2).These results agree with those reported by Abo El-nor et al., (2007); Sallam and Mahgoub (2015), they found that DM intake was increased when lactating animals fed different level of medical plant seeds. Results in Table (2) showed that the digestibility coefficients of DM, $\mathrm{OM}, \mathrm{CP}, \mathrm{EE}$ and feeding values (TDN and DCP) were significantly $(\mathrm{P}<0.05$ or $\mathrm{P}<0.01)$ increased in supplemented groups than control. These results agree with finding of Sadek et al., (2013); Sallam and Mahgoub (2015) with Egyptian buffaloes, they reported that medicinal plant seeds significantly improved the digestibility coefficient of DM, OM, CP and EE and TDN, DCP compared with the control. Also, the present results agree with finding of Salem et al., (2002); Abd El-Hakeem, (2011) they found that digestibility coefficient of DM, OM, CP and EE and TDN, DCP in lactating buffaloes increased by Yeast culture added compared with the control.

The improvement in nutrient digestibility and feeding value of supplemented groups than control Table (2) could be due to the stimulation of rumen micro flora activity through one of the following: (1decreasing number and activity of antagonistic organisms), (2- saving some micro factors to rumen micro flora, micro elements, vitamins, hormone, enzymes or unknown factors) which are required to the efficient digestion, absorption and metabolism and available as effective groups or components in medical plants), (3decreasing hazard some harmful heavy metals) and (4- minimizing effectively hazards of mycotoxins by inhibition of fungi growth and aflatoxins production. (Mohamed et al., 2003). 
Table (2). Effect of treatment on total dry matter intake (DMI) and digestibilty coefficients of lactating buffaloes, fed the experimental ration.

\begin{tabular}{|c|c|c|c|c|c|c|c|}
\hline \multirow[t]{2}{*}{ Item } & \multicolumn{3}{|c|}{ Total dry matter intake (TDMI) } & \multirow{2}{*}{\multicolumn{2}{|c|}{$\pm \mathrm{SE}$}} & \multirow[t]{2}{*}{ Sign } & \multirow[b]{2}{*}{ p.value } \\
\hline & $\mathrm{T}_{2}$ & $\mathrm{~T}_{3}$ & $\mathrm{~T}_{4}$ & & & & \\
\hline CFM Intake $_{(\mathrm{kg})}$ & $6.87^{c}$ & $7.8^{\mathrm{b}}$ & $6.76^{\mathrm{c}}$ & $8.54^{\mathrm{a}}$ & 0.49 & $*$ & 0.021 \\
\hline WS Intake $_{(\mathrm{kg})}$ & 4 & 4 & 4 & 4 & - & - & - \\
\hline $\mathrm{EC} /$ Intake $_{(\mathrm{kg})}$ & 2 & 2 & 2 & 2 & - & - & - \\
\hline $\mathrm{DMI} / \mathrm{h} / \mathrm{d}^{(\mathrm{kg})}$ & $12.87^{\mathrm{c}}$ & $13.80^{\mathrm{b}}$ & $12.76^{\mathrm{c}}$ & $14.54^{\mathrm{a}}$ & 0.49 & * & 0.021 \\
\hline Anise seeds, $(\mathrm{gm})$ & - & 50 & - & 25 & - & - & - \\
\hline Active dry yeast, (gm) & - & - & 20 & 10 & - & - & - \\
\hline \multicolumn{8}{|c|}{ Digestibilty coefficients $\%$} \\
\hline $\mathrm{DM}$ & $62.46^{\mathrm{c}}$ & $66.51^{\mathrm{b}}$ & $65.79^{\mathrm{b}}$ & $71.63^{\mathrm{a}}$ & 1.74 & $*$ & 0.034 \\
\hline OM & $67.38^{\mathrm{c}}$ & $70.62^{b}$ & $71.95^{\mathrm{b}}$ & $75.25^{\mathrm{a}}$ & 1.11 & $* *$ & 0.0068 \\
\hline $\mathrm{CP}$ & $64.25^{\mathrm{c}}$ & $70.47^{\mathrm{b}}$ & $71.44^{\mathrm{b}}$ & $74.53^{\mathrm{a}}$ & 0.85 & $* *$ & 0.0002 \\
\hline $\mathrm{EE}$ & $66.22^{\mathrm{b}}$ & $76.25^{\mathrm{a}}$ & $77.23^{\mathrm{a}}$ & $75.95^{\mathrm{a}}$ & 1.52 & $* *$ & 0.0028 \\
\hline $\mathrm{CF}$ & 53.95 & 55.74 & 60.67 & 59.60 & 2.13 & NS & 0.163 \\
\hline NFE & 69.47 & 70.92 & 70.26 & 71.50 & 1.32 & NS & 0.729 \\
\hline \multicolumn{8}{|l|}{ Feeding value $\%$} \\
\hline TDN & $61.74^{\mathrm{c}}$ & $64.66^{\mathrm{b}}$ & $65.27^{\mathrm{a}}$ & $66.11^{\mathrm{a}}$ & 1.28 & $*$ & 0.0168 \\
\hline DCP & $9.20^{\mathrm{c}}$ & $10.09^{\mathrm{b}}$ & $10.23^{b}$ & $10.67^{\mathrm{a}}$ & 0.12 & $* *$ & 0.0002 \\
\hline
\end{tabular}

${ }^{a, b, \mathrm{~b}}$ Means within the same row having different superscripts are significantly different $(\mathrm{P}<0.05)$

$\mathrm{NS}=$ Not significant $(\mathrm{P}>0.05), *=(\mathrm{P}<0.05), * *=(\mathrm{P}<0.01)$

$\mathrm{T}_{1=}$ control group (basal ration); $\mathrm{T}_{2}=$ basal ration plus $50 \mathrm{~g}$ Anise seeds $/$ headlday; $\mathrm{T}_{3}=$ basal ration plus $20 \mathrm{~g}$ active dry yeast $/ \mathrm{head} / \mathrm{day} ; \mathrm{T}_{4}=$ basal ration plus $25 \mathrm{~g}$ Anise seeds $+10 \mathrm{~g}$ Active dry yeast /head/day.

\section{Blood parameters.}

Cholesterol and triglycerides levels were decreased significantly $(\mathrm{P}<0.01)$ in treated buffaloes $\left(\mathrm{T}_{2}, \mathrm{~T}_{3}, \mathrm{~T}_{4}\right)$ compared with control group (Table 3 and Fig 1). This result might be attributed in somehow to the higher nutritive values of medicinal herbs ration. However, it was of interest to point out to the fact that not all medicinal herbs to have similar positive influences on reducing cholesterol biosynthesis in animal blood. These results are in agreement with those reported that by Othman (2005) found that medicinal plant seeds additives significantly decreased Cholesterol and triglycerides levels in lactating animals. Similarly, Zeid (2004) showed that total lipids and cholesterol concentrations were lower $(\mathrm{P}<0.05)$ with both of Nigella sativa and Chamomile when they compared with the control ration. Also, the present results are in agreement with those reported by Temim et al., (2009) found that supplementation of dairy cows with Saccharomyces cerevisiae significantly lowered the cholesterol and triglycerides concentration levels.

Table (3). Effect of treatments on some blood parameters.

\begin{tabular}{lcccccc}
\hline \multirow{2}{*}{ Item } & \multicolumn{3}{c}{ Treatments, LSM \pm S.E } & Sign & P.Value \\
\cline { 2 - 5 } & $\mathrm{T}_{1}$ (control) & $\mathrm{T}_{2}$ & $\mathrm{~T}_{3}$ & $\mathrm{~T}_{4}$ & & 0.001 \\
\hline Cholesterol (mg/dl) & $186.9 \pm 7.95^{\mathrm{a}}$ & $145.9 \pm 7.95^{\mathrm{b}}$ & $148.6 \pm 7.95^{\mathrm{b}}$ & $138.2 \pm 7.95^{\mathrm{b}}$ & $* *$ & 0.008 \\
Triglyceride (mg/dl) & $45.52 \pm 5.16^{\mathrm{a}}$ & $34.26 \pm 5.16^{\mathrm{b}}$ & $38.20 \pm 5.16^{\mathrm{b}}$ & $35.66 \pm 5.16^{\mathrm{b}}$ & $* *$ & $*$ \\
T3 (ng/dl) & $1.16 \pm 0.01^{\mathrm{c}}$ & $1.33 \pm 0.76^{\mathrm{b}}$ & $1.37 \pm 0.59^{\mathrm{b}}$ & $1.79 \pm 0.05^{\mathrm{a}}$ & $*$ & 0.052 \\
T4 (ng/dl) & $35.73 \pm 1.98^{\mathrm{c}}$ & $47.24 \pm 7.38^{\mathrm{b}}$ & $48.1 \pm 7.45^{\mathrm{b}}$ & $52.5 \pm 1.00^{\mathrm{a}}$ & $*$ & 0.017 \\
\hline
\end{tabular}

${ }^{a, b, c}$ Means within the same row having different superscripts are significantly different $(P<0.05)$

$*=(P<0.05) ; \quad * *=(P<0.01)$.

The highest blood plasma Triiodthyronine $\left(\mathrm{T}_{3}\right)$ and thyroxine $\left(\mathrm{T}_{4}\right)$ hormones levels were found with buffaloes fed $\mathrm{T}_{4}$ ration followed by $\mathrm{T}_{3}$ treatment then $\mathrm{T}_{2}$, while the lowest blood plasma levels of $\mathrm{T} 3$ and $\mathrm{T} 4$ 
hormones was found with the control group buffaloes. The differences were significant $(\mathrm{P}<0.05)$ among treatments (Table 2 and Fig 2). The significant increase in the secretion of thyroid hormones $\left(\mathrm{T}_{3}\right.$ and $\mathrm{T}_{4}$ $\mathrm{ng} / \mathrm{dl}$ ) in $\mathrm{T}_{4}, \mathrm{~T}_{3}$ and $\mathrm{T}_{2}$ treatments might be due to (1) the increase of carbohydrate, fat and protein metabolism, which it was reflected in a positive effect on digestibility coefficient of carbohydrate (as NFE), fat (as EE) and protein (as CP) it was reported in literature by Kassab (2007). These results are in agreement with those reported that by Zanouny et al., (2013) they found that added medicinal plant seeds significantly increase $(\mathrm{P}<0.05)$ the level of $\mathrm{T}_{3}$ and $\mathrm{T}_{4}$ hormone concentrations in Ossimi lambs. Also, the present results are in agreement with the finding of Yousef et al., (1996) found that, feeding on diet supplemented with $15 \mathrm{~g}$ $\mathrm{YC} / \mathrm{h} / \mathrm{d}$ increased $\mathrm{T}_{3}$ hormone level of lactating buffaloes during summer season.

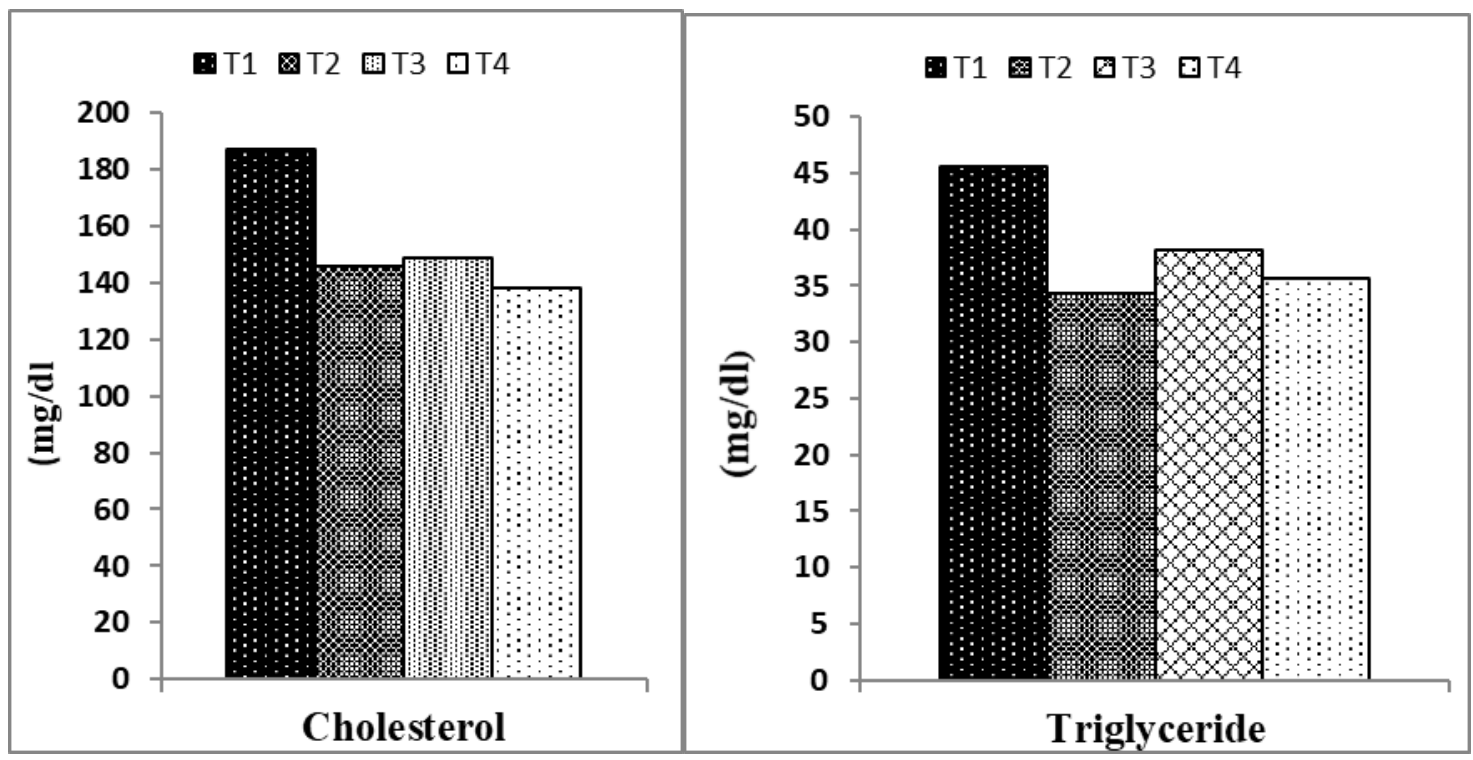

Figure (1): Cholesterol and Triglyceride levels.

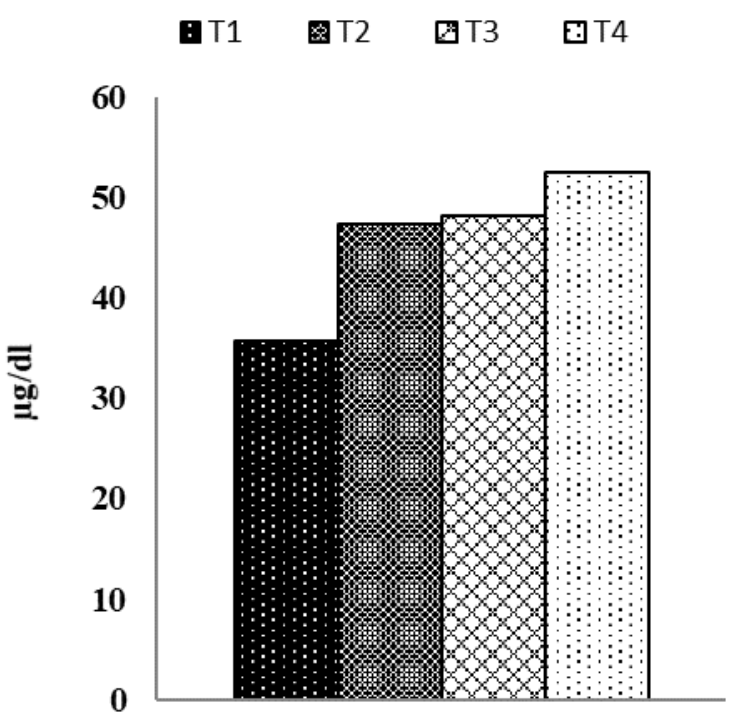

Thyroxine

Figure (2): Triiodthyronine (T3) and Thyroxine (T4) levels. 


\section{Sallam et al.}

\section{Milk Yield and Composition.}

The total milk yield for $\mathrm{T}_{1}, \mathrm{~T}_{2}, \mathrm{~T}_{3}$ and $\mathrm{T}_{4}$ treatments were 540.01, 621.20, 641.88 and $670.86 \mathrm{~kg}$, respectively. Also, the overall daily milk means for $\mathrm{T}_{1}, \mathrm{~T}_{2}, \mathrm{~T}_{3}$ and $\mathrm{T}_{4}$ treatments were 5.14, 5.92, 6.11 and $6.39 \mathrm{~kg} / \mathrm{h} / \mathrm{d}$, respectively (Table 4). Results in Table (4) and Fig (3) revealed that total and daily milk yield in the treated animals were significantly $(\mathrm{P}<0.05)$ higher compared to the control.

The increase in milk yield by addition of Anise seeds may be due to the galactogoetic effect of active components that Anise may contain. El-komey, (1996) found that the term galactopoietic arises from medicinal seeds Anise and Caraway which contain active substances which stimulate milk secretion. Sallam et al., (2012) reported that Anise seeds diet supplementation improves milk yield in Ossimi ewes. The improvement in milk yield could be due to biological properties of Anise oil that are inhibiting for bacterial (Sagdic and Ozcan, 2003) and Fungi growth (Soliman and Badeaa, 2002), which stimulating the secretion of digestive enzymes and appetizing. In addition, the estrogenic agents of Anise can also contribute to better milk secretion (Albert-Buleo, 1980). Concerning the effect of supplementation Yeast culture in diets on milk yield, many investigator reported that milk yield had increased significantly $(\mathrm{P}<0.05$ or $\mathrm{P}<0.01)$ by dietary Yeast culture addition (Khattab et al., (2010); Mousa et al., (2012).

The improvement in milk yield, in the present study may also due to the higher DM, OM, CP, EE, and NFE digestibility's and the feeding value expressed as TDN and DCP (Table 2). Moreover, the increase of milk yield from treated buffaloes in the present study may be due to the positive effect of Anise seeds and Active dry Yeast supplementation on secretion of thyroid hormones and the level of prolactin hormone concentration. The efficiencies in milk yield calculated as DMI/kg milk yield and milk yield /DMI were improved $(\mathrm{P}<0.05)$ in treated groups $\left(\mathrm{T}_{2}, \mathrm{~T}_{3}\right.$ and $\left.\mathrm{T}_{4}\right)$ as compared with control group (Table 4). These results are in agreement with those reported by Abo El-Nor et al., (2007); Sallam and Mahgoub (2015), they found that DMI/kg milk yield and milk yield /DMI in Egyptian buffaloes were improved $(\mathrm{P}<0.05)$ in treated groups as compared with the control by supplementation medicinal plant seeds. Milk fat, lactose, total solids, solid not fat and ash contents were higher $(\mathrm{P}<0.05$ or $\mathrm{P}<0.01)$ in $\mathrm{T}_{2}, \mathrm{~T}_{3}$ and $\mathrm{T}_{4}$ than control. While, milk protein content did not differ significantly $(\mathrm{P}>0.05)$ between treatments (Table 4 and Fig 4$)$.

Table (4). Milk yield and composition of lactating buffaloes as affected by dietary treatments.

\begin{tabular}{|c|c|c|c|c|c|c|c|}
\hline \multirow[b]{2}{*}{ Item } & \multicolumn{4}{|c|}{ Treatment } & \multirow[b]{2}{*}{ S.E } & \multirow[b]{2}{*}{ Sig } & \multirow[b]{2}{*}{ P.Value } \\
\hline & $\mathrm{T}_{1}$ (control) & $\mathrm{T}_{2}$ & $\mathrm{~T}_{3}$ & $\mathrm{~T}_{4}$ & & & \\
\hline Lactation length(d) & 105 & 105 & 105 & 105 & & & \\
\hline Total milk yield (kg) & $540.01^{\mathrm{b}}$ & $621.20^{\mathrm{a}}$ & $641.88^{\mathrm{a}}$ & $670.86^{\mathrm{a}}$ & 49.93 & $*$ & 0.037 \\
\hline \multirow[t]{2}{*}{ Daily milk yield (kg) } & $5.14^{\mathrm{b}}$ & $5.92^{\mathrm{a}}$ & $6.11^{\mathrm{a}}$ & $6.39^{\mathrm{a}}$ & 0.48 & $*$ & 0.036 \\
\hline & \multicolumn{3}{|c|}{ Feed efficiency } & & & & \\
\hline $\mathrm{DMI}(\mathrm{kg} / \mathrm{h} / \mathrm{d})$ & $12.87^{\mathrm{c}}$ & $13.80^{\mathrm{b}}$ & $12.76^{\mathrm{c}}$ & $14.54^{\mathrm{a}}$ & 0.49 & $*$ & 0.021 \\
\hline DM I/ milk & $2.50^{\mathrm{a}}$ & $2.33^{\mathrm{b}}$ & $2.09^{c}$ & $2.28^{\mathrm{b}}$ & 0.18 & $*$ & 0.031 \\
\hline \multirow[t]{2}{*}{ Milk/DMI } & $0.40^{\mathrm{b}}$ & $0.44^{\mathrm{a}}$ & $0.48^{\mathrm{a}}$ & $0.44^{\mathrm{a}}$ & 0.04 & $*$ & 0.042 \\
\hline & \multicolumn{3}{|c|}{ Milk composition (\%) } & & & & \\
\hline Fat & $5.90^{\mathrm{c}}$ & $6.78^{\mathrm{a}}$ & $6.31^{\mathrm{b}}$ & $6.62^{\mathrm{ab}}$ & 0.13 & $* *$ & 0.0003 \\
\hline Protein & 3.52 & 3.48 & 3.34 & 3.61 & 0.9 & NS & 0.221 \\
\hline Lactose & $4.34^{\mathrm{c}}$ & $4.79^{\mathrm{ab}}$ & $4.59^{\mathrm{bc}}$ & $4.92^{\mathrm{a}}$ & 0.11 & $* *$ & 0.0032 \\
\hline Total solid & $14.34^{\mathrm{b}}$ & $15.80^{\mathrm{a}}$ & $14.94^{\mathrm{b}}$ & $15.74^{\mathrm{a}}$ & 0.21 & $* *$ & 0.0001 \\
\hline Solid not fat & $8.44^{\mathrm{c}}$ & $9.02^{\mathrm{ab}}$ & $8.63^{b c}$ & $9.12^{\mathrm{a}}$ & 0.20 & $*$ & 0.013 \\
\hline Ash & $0.69^{\mathrm{b}}$ & $0.73^{\mathrm{b}}$ & $0.82^{\mathrm{a}}$ & $0.70^{\mathrm{b}}$ & 0.02 & $* *$ & 0.0003 \\
\hline
\end{tabular}

${ }^{a, b, c}$ Means within the same row having different superscripts are significantly different $(P<0.05)$

NS $=$ Not significant $(P>0.05), *=(P<0.05) ; * *=(P<0.01)$.

In some reports, it was demonstrated that many plants increased milk production in animals through the induction of lactogenic hormone (prolactin) Lompo-Ouedraogo et al. (2004) and Patel and Kanitkar, (1969). Some plants contain estrogenic substances such as anethole that increase the secretion of milk. Structurally, anethole is similar to dopamine and shows a competitive antagonism at the dopamine receptor site. Thus, it can increase the liberation of prolactin and induce the production of milk (Lis-Balchin., 2006). P. anisum seeds have many components such as Tanethole (Chandler and Hawkes., 1984), and the lactogenic activity of this plant may be related to this constituent. In addition, the growth of pups and gain weight in treated 
groups may be attributed to induction of milk production and milk constituents. These results are in agreement with those reported by many investigators Salem et al. (2002); Khattab et al. (2010) and Sallam and Mahgoub (2015).

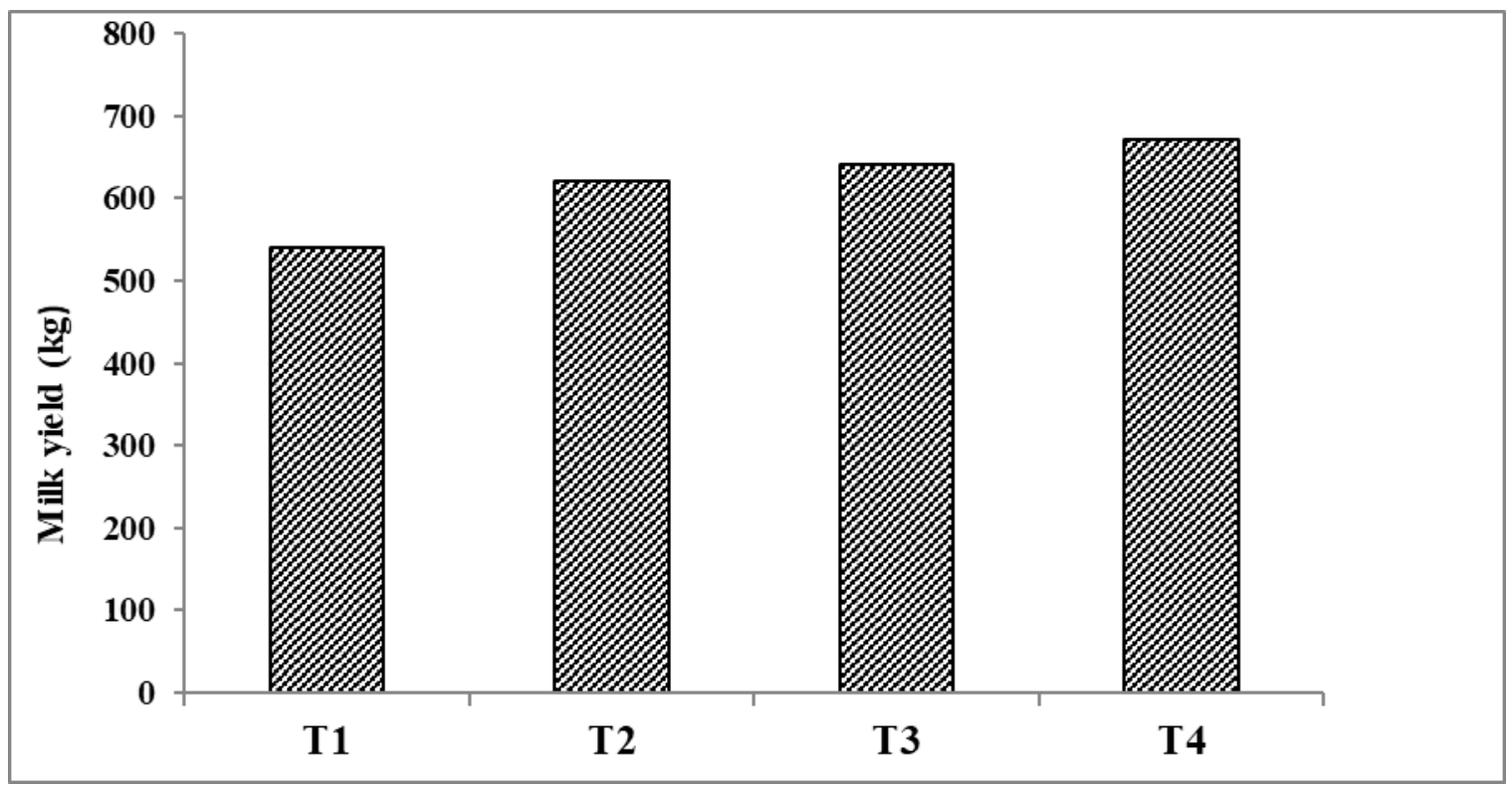

Figure (3): Total milk yield (kg)

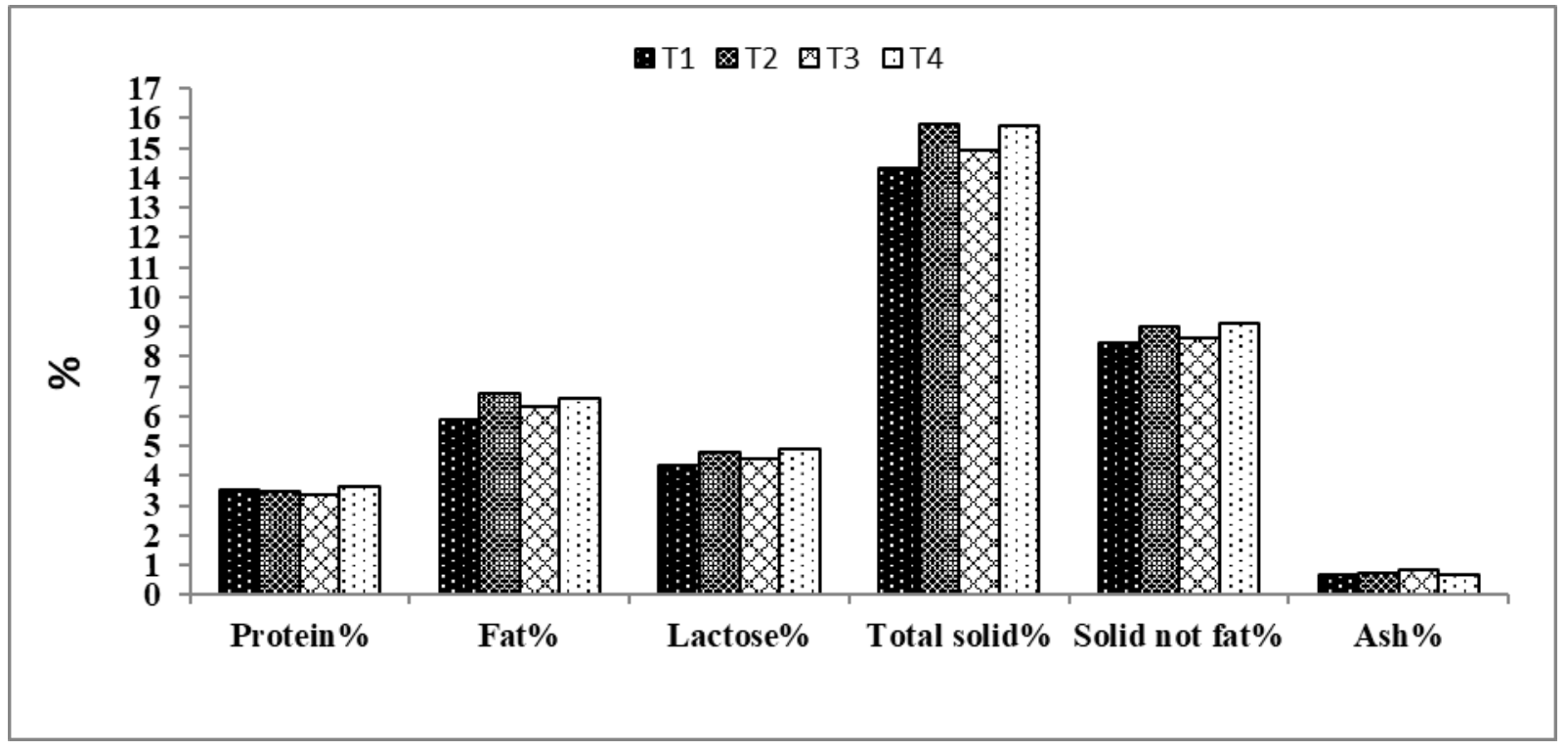

Figure (4): Milk composition.

\section{CONCLUSION}

Based on the results of this study, it may be concluded that Anise seeds and Active dry Yeast can successfully be used as feed additives in the ration of lactating buffaloes for increase milk yield by about 19 


\section{Sallam et al.}

$\%$ more than the unsupplemented groups. Also, the quality of milk yield was improved. Levels of cholesterol and triglyceride were decreased in the blood of treated buffaloes than that of control group.

\section{ACKNOWLEDGEMENTS}

The authors would like to express their most sincere gratitude and appreciation to all colleagues and employees are in the Animal Production Department, Faculty of Agriculture, Al-Azhar University, Assiut Branch, Assiut, Egypt for their assistance with animal care and sample collection throughout the duration of the experiment.

\section{REFERENCES}

Abd El-Hakeem, A.M. (2011). Some nutrition studies on lactating buffaloes. M.Sc. Thesis, Fac, Agric, Minia. Egypt.

Abdel-Aziz, A. (2005). Genetic improvement of milk yield in Egypt: a buffaloes prospective. Proc. $2^{\text {nd }}$ Conf. Anim. Prod. Res., Sakha, 2005, 27-29 Sept., p. 25-32.

Abo El-Nor, S.A.H. (1999). Influence of fenugreek seeds as a galactagogue on milk yield, milk composition and different blood biochemical of lactating buffaloes during mid-lactation. Egypt.J.Sci., 27(2):231.

Abo El-Nor, S.A.H., H.M. Khattab., H.A. Al-Alamy., F.A. Salem and M.M. Abdou (2007). Effect of some medicinal plants seeds in the rations on the productive performance of lactating buffaloes. Int. J. Dairy Sci 2 (4), 348-355.

Albert-Buleo, M. (1980). Fennel and Anise estrogenic agents. Ethno pharmacology,(2):337-344.

AOAC (1995). Official Methods of Analysis of AOAC International, 16th ed. Agricultural, Chemicals, Contaminats, Drugs, vol.1.Washington, D. C, USA.

Chandler, R.F and D. Hawkes (1984). Aniseed: spice, flavor, drug .J Canadian Pharmacol, (117): $28-29$.

Chopra, I.J., D.H. Solomon and G.N. Beall (1971). Radiommunoassay for measurement of Triiodothyronine in Human serum. J. Glin. Invest. 50:2033.

Dowining, J.A., J. Joss., P. Connel and R.J. Scaramuzzi (1995). Ovulation rate and the concentration of gonadotrophic and metabolic hormones in ewes' lupin grain. Journal of Reproduction and Fertility.103, 137.

Duncan, D.B. (1955). Multiple range and multiple F-tests.Bioetrics, 11:1-42.

Economides, S. (1986). Comparative studies of sheep and goats milk yield and composition and growth rate of lambs and kids. J Agric. Sci (camb): 106 - 477.

El-Ashry, M.A., A.M. Kholif., H.A. El-Alamy and T.A. El-Hamamsy (2001). Effect of different yeast cultures supplementation to diet on the productive performance of lactating buffaloes. Egyptian Journal of Nutrition and Feeds, 4:1, 21-33, 48.

El-Garhy, G.M. and S.M.S. Moustafa (2007): Effect of anise and dill seeds as feed additives on performance of lactating buffaloes. Egyptian J. Nutrition and Feeds 2(2):79-87.

EL-Komey, A.G. (1996). Effect of Black seeds (Nigella sativa L.) during pregnancy and lactation on mammary gland development in Rats. Alex-J-Agric. Res. 41(1):63.

Ellefson, R.D and W.T. Caraway (1976). Fundamental of clinical chemistry. P: 506.

Irvine, W.J and R.M. Standeven (1968). Serum Triiodothyronine uptake using coated charcoal in the assessment of thyroid function. J. Endoc. 41, 31.

Kassab, A.Y. (2007). Effect of protected protein on productive and reproductive performance of sheep. Ph.D. Thesis, Fac. of. Agric., Minia University, Egypt. 
Khattab, H.M., S.A.H. Abo El-Nor., S.M. Kholif., H.M. El-Sayed., O.H. Abd El-Shaffy and M. Saada (2010). Effect of different additive sources on milk yield and composition of lactating buffaloes. Livestock Science (131):8-14.

Khattab, H.M., A.Z. El-Basiony., S.M. Wakwak and B.A. Marwan (2011): Immune response and productive performance of dairy buffaloes and their offspring supplemented with black seed oil. Iranian Journal of Applied Animal Science, 1(4): 227-234.

Ling, E.R. (1963). Text book of dairy chemistry. Vol. 11. Practical Chapman and Hall. T.D. London $3^{\text {rd }}$ ed .pp. 140 .

Lis-Balchin, M. (2006). Aromatherapy science: a guide for healthcare professionals Pharmaceutical Press, London (2006).

Lompo-Ouedraogo, Z., D. van der Heide., E.M. van der Beek., H.J. Swarts., J.A. Mattheij and L. Sawadogo (2004). Effect of aqueous extract of Acacia nilotica ssp adansonii on milk production and prolactin release in the rat. J Endocrinol, 182, pp. 257-266.

Ministry of Agriculture, Dokki, Egypt (2003). Animal Report for Agriculture Production, Agriculture Economy Research Institute, Egypt (In Arabic).

Mohamed, A.H., B.E. El-Saidy and L.A. El-Seidi (2003). Effect of some medicinal plants supplementation on: 1- digestibility, nutritive value, rumen fermentation and some blood biochemical parameters in sheep. Egyptian J. Nutrition and Feeds, 6(2):139.

Mousa, Kh.M., O.M. El-Malky., O.F. Komonna and S.E. Rashwan (2012). Effect of Some Yeast and Minerals on the Productive and Reproductive Performance in Ruminants. Journal of American Science, $8(2)$.

Othman, A.A. (2005). Effect of Some Natural Antioxidants on Lambs Performance. M. Sc. Thesis, Animal Production Department, Faculty of Agriculture, Cairo University, Cairo, Egypt.

Patel, A.B. and U.K. Kanitkar (1969). Asparagus racemosus willd-form bordi, as a galactogogue, in buffaloes. Indian Vet J, pp. 718-721.

Sadek, I.H., M.A.I El-Sysy and Sh. M. Fouda (2013). Effect of Medicinal Herbs Supplementation on Digestibility and Growth Performance of Growing Buffalo calves. Egypt. J. of Appl. Sci., 28 (10) 331349.

Sağdiç, O. and M. Özcan (2003). Antibacterial activity of Turkish spice hydrosols. Food Control, 14, 141 143.

Salem, F.A., S.H. Hassanin and A.A. El-Shewy (2002). Effect of Saccharomyes cerevisiae supplementation on milk yield and composition, digestibility and some blood constituents in lactating buffaloes. Prod. 1st Ann. Sc. Conf. Anim. and Fish Prod., Mansoura 24 \& 25 Sep., 2002.

Sallam, M.T and A.A.S. Mahgoub (2015). Effect of crushed Fenugreek seeds as feed additives on lactating Egyptian buffaloes performance, milk yield, milk composition and some blood parameters. $1^{\text {st }}$ World. Conference on innovative Animal, Nutrition and Feeding.Wianf.15 - 17 October, 2015, Budapest, Hungary.

Sallam, M.T., A.A. Abd El-Ghani., S.S. Habeb., A.A. Abd El-Hakeam and S.A. Mohamed (2012). Effect of some medicinal seeds as feed additives on lactating Ossimi ewes' performance, milk yield, milk composition, lamb growth and some relevant blood Hormones. International Cof, Rome: 29 October 1November, 2012.

SAS (2008). SAS User's Guide: Statistic. SAS Institute, Cary, NC, USA.

Shehata, O.K. (1971). Lecture in animal production (in Arabic) Animal production Dep. Fac. Agric. Ainshams Univ. Shoubra EL-Kemah; Cairo; Egypt.

Soliman, K.M and R.I. Badeaa (2002). Effect of oil extracted from some medicinal plants on different mycotoxigenic fungi. Food and Chemical Toxicology, 40, 1669-1675.

Stein, E.A. (1987). Lipids, lipoprotein and apolipoproteins in: N.W. Tietz, ed. Fundamental of clinical chemistry, $3^{\text {rd }}$ ed. Philadelphia: W. B. Saunders; 448. 


\section{Sallam et al.}

Temim, S., A. Boudjenah., B. Djellout., S. Bouzerd., M.E. Atif., F. Hafsi., F. Ghozlae and H.A. Baziz (2009). Effect of Saccharomyces cerevisiae dietary supplementation on the zootechnical performance and blood components of dairy cows during peripartum .Livestock Research for Rural Development. 21. (11).187.34.

Van Keulen, J. and B.A. Young (1977). Evaluation of acid insoluble ash as a natural marker in ruminant digestibility studies. J. Amin.Sci., 44:282.

Yousef, H.M., K.A. El-Masry and A.L. Aboulunga (1996). Effect of dried live yeast supplement on haemobiochmeical level and milk production responses of lactating buffaloes under hot summer condition in Egypt. Egyptian J.Anim.Prod. (33):11-21.

Zanouny, A.I., A.K.I. Abd-El moty., M.A.A. El-Barody., M.T. Sallam and A.A. Abd El-Hakeam (2013). Effect of Supplementation with Nigella Sativa Seeds on Some Blood Metabolites and Reproductive Performance of Ossimi Male Lambs. Egyptian Journal of Sheep and Goat Sciences, 8 (1): 47-56.

Zeid, A.M.M. (2004). Impact of using different feed additives on the performance of growing Frisian calves. Journal of Agriculture Sciences.12, 167-175.

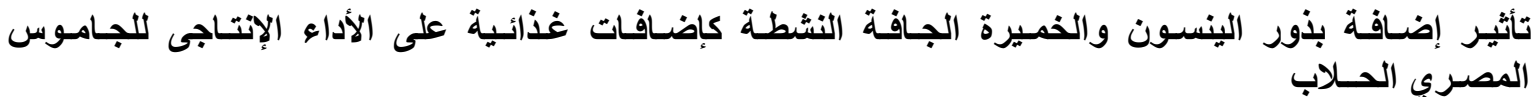

\footnotetext{
محمد الطاهر سلام 1 و محمد عبد الفتاح البارودى1 و محترم عبدالله محمد² و حمدان محمد توفيق2

قسم الانتاج الحيوانى ـ كلية الزراعة - جامعة المنيا1

قسم الانتاج الحيوانى ـ كلية الزراعة - جامعة الازهر بأسيوطُ
}

تم دراسة تاثير اضافة بذور الينسون والخميرة الجافة النشطة لعلائق الجاموس المصري على انتاج اللبن وتركيبه وبعض مقاييس الدم.

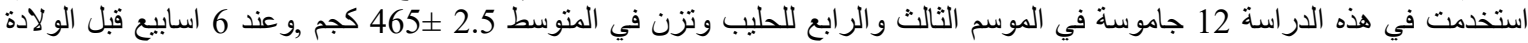
المتوقعة قسمت الحيو انات عشو ائيا الى 4 مجاميع منساوية:

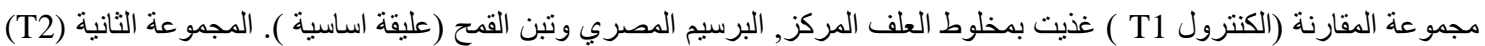

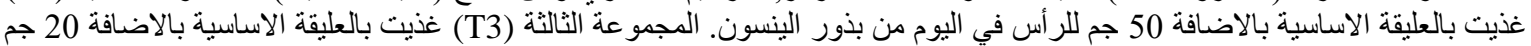

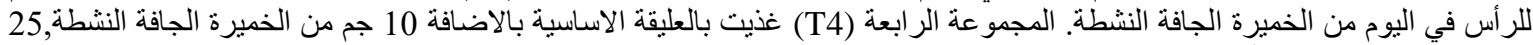

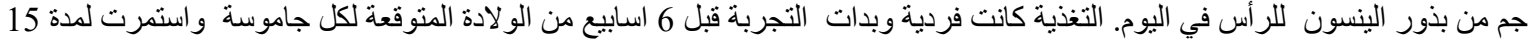

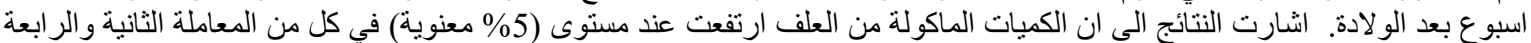

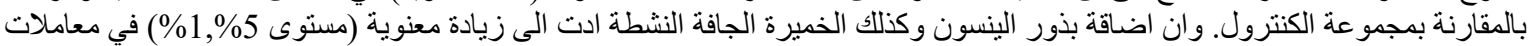

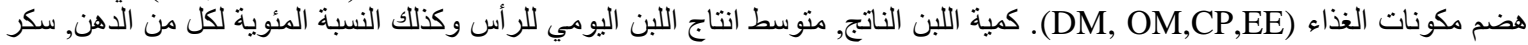

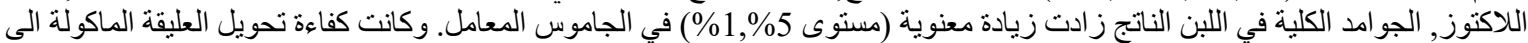

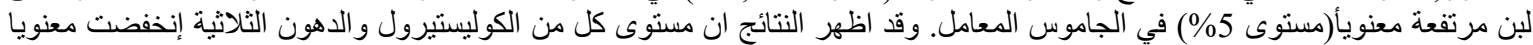

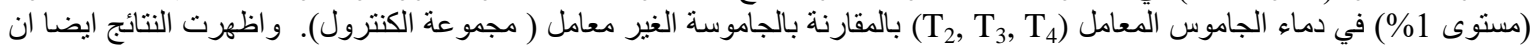

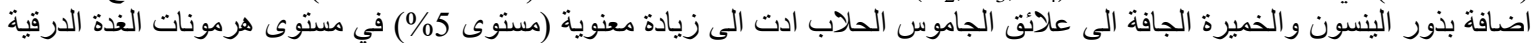

. T3,T4

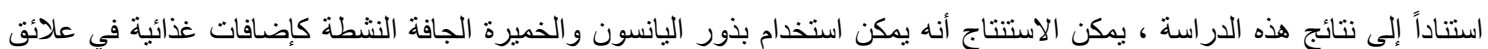

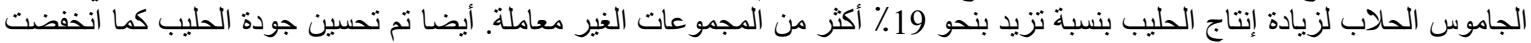

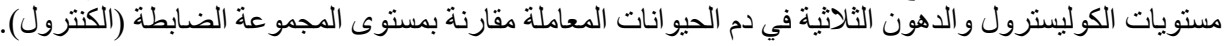

